\title{
A Culture of Justification or a Culture of Presumption? The Turn to Procedural Review and the Normative Function of Proportionality at the European Court of Human Rights
}

\author{
Alain Zysset
}

\section{A. Introduction}

The European Court of Human Rights ('the Court' or 'ECtHR') has recently consolidated a 'turn to procedural review' ('TPR') in its role as supreme interpreter of the European Convention on Human Rights ('ECHR'). In a nutshell, the TPR adjusts the object of the Court's scrutiny; rather than reviewing the (substantive) merits of cases independently within the proportionality assessment, the Court focuses on the quality of the domestic procedure by which the (potentially infringing) law under consideration was adopted and applied. This then informs the merits stage of evaluation.

While the literature has documented the TPR in the Court's case law, critical and evaluative accounts of the turn are still scarce. What is the broader significance of the TPR for our understanding of the Court's nature, function and legitimacy? In this article, I suggest remedying this deficit by evaluating the TPR from a theoretical and normative perspective. I concentrate on the relationship between the TPR and proportionality analysis. With a view to building an analytical framework, I employ the well-established distinction between a culture of authority and a culture of justification. In brief, a culture of authority is exemplified when a court reviews the process of creation of an infringing law as its procedural review. In contrast, the rise of proportionality assessments in constitutional and human rights review exemplifies a culture of justification because it scrutinizes a wider spectrum of reasons that may ground the interference. As we shall see, however, the TPR often has implications for the Court's proportionality analysis: I argue that the TPR indicates a reversed dynamic towards a culture of authority.

A culture of authority has two main variants. First, the Court may exemplify a culture of authority by relying on the text of the Convention and on established methods of adjudication (e.g. 'evolutive and dynamic', 'autonomous concepts', or 'practical and effective') or by allocating a margin 
of appreciation to the respondent state party as 'better placed' (empirically) to operate the balancing between conflicting rights and interests. Second, it may exemplify a culture of authority by relying on the quality of the procedure by which the piece of legislation is adopted by the appropriately situated decision-making body. The TPR corresponds to the second variant: the Court places the burden of legitimate authority on the domestic processes (including taking into account of ECHR standards), which may lead - but not necessarily - the Court to allocate a margin of appreciation to the respondent state.

This argument has implications for how one normatively evaluates the TPR. Indeed, it has been argued that the TPR may reinforce the democratic legitimacy of the Court's rulings, as we shall see. I argue that the TPR rather points to a worrying retreat of the Court, which I call a culture of presumption. This culture disables the core normative function of proportionality analysis, a key component of effective protection of human rights. More fundamentally, I argue, the TPR runs the risk of retreating from the very concept of human rights understood as the 'right to justification.'1

This chapter proceeds in two steps. In section B., I define the TPR and the context(s) of adjudication in which it operates at the Court. I specifically examine the link between the TPR and proportionality. In section C., I develop the distinction between justification and authority and explain how relevant it is to evaluate the TPR. I then argue that the TPR exemplifies the return to a culture of authority through a discussion of the normative function of proportionality.

\section{B. The turn to procedural review ('TPR')}

In this section, I introduce the main features of the TPR in the practice of the Court in recent years. This section also aims to show that while the TPR is now well understood at a descriptive level, it has not yet been comprehensively conceptualised and normatively evaluated. I aim to remedy this deficit in later sections of the article.

The TPR in the practice of the Court is now well documented in the literature. Using this growing literature, I suggest reconstructing the TPR in two steps. First, one may reconstruct the typical context(s) of the TPR - that is, where the turn from substantive to procedural review occurs (or

1 Forst, 'The Justification of Human Rights and the Basic Right to Justification: A Reflexive Approach' (2010) 120:4 Ethics, 711. 
when they co-exist) in the reasoning of the Court. Second, one may ask about the wider implications of the TPR. In other words, what gets lost when the Court's review is predominantly procedural? This second step is properly normative and will require, I shall explain, an normative account of proportionality analysis that I offer in section C.

In terms of its context(s), the TPR predominantly concerns both the procedural obligations of an ECHR article, on the one hand, and the review of the domestic procedure and its impact on the merits of a case, on the other. The literature here has shown that the former context concerns, most importantly, Articles 5, 6, and 13 of the ECHR. ${ }^{2}$ However, the same literature has also highlighted how procedural obligations can be read into other articles of the ECHR, in particular Articles 2, 3, 8 and Article 1 Protocol 1. The issue of the right to abortion under Article 8 of the Convention and the case of $A, B$ and $C v$. Ireland is illustrative: while emphasising that 'the profound moral views of the Irish people as to the nature of life' 3 justifies allocating a wide margin of appreciation to the Irish state, the Court nonetheless found a violation of Article 8 on distinctively procedural grounds (for one of the applicants):

The authorities failed to comply with their positive obligation to secure to the third applicant effective respect for her private life by reason of the absence of any implementing legislative or regulatory regime providing an accessible and effective procedure by which the third applicant could have established whether she qualified for a lawful abortion in Ireland. ${ }^{4}$

The latter context concerns the Court focusing on the domestic procedure of decision-making (parliamentary, administrative and judicial), which then informs and alters the substantive merits of a case. This type of procedural review, which the literature has called 'procedural review stricto sensu', ${ }^{5}$ is the focus of this chapter. For that portion of the analysis, it

2 Brems, 'Procedural Protection: An Examination of Procedural Safeguards Read into Substantive Convention Rights' in Brems and Gerards (eds), Shaping Rights in the ECHR: The Role of the European Court of Human Rights in Determining the Scope of Human Rights (2014), 137.

3 ECtHR, Judgment (GC), 16 December 2010, A, B and C $v$ Ireland, Application No. 25579/05, para. 241.

4 ECtHR, Judgment (GC), 16 December 2010, A, B and C $v$ Ireland, Application No. 25579/05, para. 267.

5 Arnardóttir, 'The "Procedural Turn" under the European Convention on Human Rights and Presumptions of Convention Compliance' (2017) 15:1 Int. J. Const. Law, 9. 
appears that the Court tends to refrain from reviewing the balancing performed by the domestic authorities between the protected provision and the norm interfering with it on its own terms, or at least assigns greater weight to the quality of the domestic procedure in that same balancing step of the proportionality test.

Refraining from or limiting the review of the balancing phase of the proportionality test is not new to the practice of the Court; it has long been shown that the Court may simply refrain from balancing or balance but still allocate a margin of appreciation to the respondent state. ${ }^{6}$ Yet, the emphasis on domestic procedures may also operate as another, more principled approach to justify the application of the margin. As Nussberger explains, 'when States are free to decide a case in different ways without violating the Convention, the inclusiveness and transparency of the decision-making process is the most relevant element for the Court to control." ${ }^{7}$

In that second context, the TPR is most operative when the Court faces an acute conflict between two protected rights with particular emphasis on Articles 8-11. This is the case for instance in Von Hannover v. Germany (No. 2) in which the Court had to balance freedom of expression (Article 10) against the right to private life (Article 8):

The Court observes that, in accordance with their case-law, the national courts carefully balanced the right of the publishing companies to freedom of expression against the right of the applicants to respect for their private life. In doing so, they attached fundamental importance to the question whether the photos, considered in the light of the accompanying articles, had contributed to a debate of general interest. They also examined the circumstances in which the photos had been taken. ${ }^{8}$

In this case, the Court paid particular attention to whether two photographs depicting a royal family on holiday contributed to a debate of public interest, which is deemed essential to the Court's 'democratic soci-

6 Letsas, 'Two Concepts of the Margin of Appreciation' (2006) 26:4 Oxf. J Leg. Stud., 705.

7 Nussberger, 'Procedural Review by the ECHR: View from the Court' in Brems and Gerards (eds) Procedural Review in European Fundamental Rights Cases (2017), 161 (174).

8 ECtHR, Judgment (GC), 7 February 2012, Von Hannover $v$ Germany (No. 2), Application Nos. 40660/08 and 60641/08, para. 124. 
ety." In the words of Gerards, this depicts a situation where the Court 'generally has to accept the outcomes of such a (non-problematic) procedure, even if it reflects a different balance or a different choice than the Court's judges would have preferred.' ${ }^{10}$ For positive obligations, ethical dilemmas and/or conflicts of rights, the Court often states that domestic authorities are 'better' placed to review the substantive merits of the case, which is the usual route to allocate the margin of appreciation. In $A, B$ and $C v$. Ireland, the Court for instance concluded that:

by reason of their direct and continuous contact with the vital forces of their countries, the State authorities are, in principle, in a better position than the international judge to give an opinion, not only on the 'exact content of the requirements of morals' in their country, but also on the necessity of a restriction intended to meet them. ${ }^{11}$

This justification is epistemic in that the Court claims not to have the necessary empirics to conduct the balancing on its own terms, which often prompts the Court to allocate the margin. That said, the TPR is also operating when it defers to domestic authorities qua democratic authorities. This is salient for example in S.A.S. v. France, where the Court faced the question of the wearing of the full-face veil in public under Article 8:

In such circumstances, the Court has a duty to exercise a degree of restraint in its review of Convention compliance, since such review will lead it to assess a balance that has been struck by means of a democratic process within the society in question. The Court has, moreover, already had occasion to observe that in matters of general policy, on which opinions within a democratic society may reasonably differ widely, the role of the domestic policy-maker should be given special weight. ${ }^{12}$

9 Zysset, 'Freedom of expression, the right to vote, and proportionality at the European Court of Human Rights: an internal critique' (2019) 17:1 Int. J. Const. Law, 230.

10 Gerards, 'The Prism of Fundamental Rights' (2012) 8:2 Eur. Const. Law Rev., 173 (173).

11 ECtHR, Judgment (GC), 16 December 2010, A, B and C $v$ Ireland, Application No. 25579/05, para. 232.

12 ECtHR, Judgment (GC), 1 July 2014, S.A.S. v France, Application No. 43835/11, para. 154. 
The Court held that view after having emphasised the subsidiary role of the Court's system:

it is also important to emphasise the fundamentally subsidiary role of the Convention mechanism. The national authorities have direct democratic legitimation and are, as the Court has held on many occasions, in principle better placed than an international court to evaluate local needs and conditions. In matters of general policy, on which opinions within a democratic society may reasonably differ widely, the role of the domestic policy-maker should be given special weight. ${ }^{13}$

This brief overview helps identify the various pieces of the puzzle forming the context of the TPR: positive obligations, ethical dilemmas, conflicts of rights, the margin of appreciation, the proportionality test, and the principle of subsidiarity. These elements may be placed in the reversed order: the principle of subsidiarity explains and (from the Court's perspective) justifies why it concentrates on the domestic procedure as the locus of review, particularly when it has to review acute conflicts of rights, ethical dilemmas, and positive obligations. The margin of appreciation is only a contingent and not a necessary implication of the Court's emphasis on procedure. Subsidiarity provides the primary justification, and one may view it in the context of the amendment to the Preamble to the ECHR in Protocol 15. ${ }^{14}$ In terms of its consequences, the potential impact on the proportionality analysis and therefore on its normative function is noteworthy. Regardless, the procedural and substantive review of the analysis can likewise co-exist and do not necessarily function as substitutes for one another. The Court may acknowledge that the domestic authority considered Convention standards but still review the substantive merits in its own terms and diverge from the domestic decision. ${ }^{15}$

Having described the relevant context in which the TPR operates, I suggest specifying the object of the TPR stricto sensu. In the broadest terms, the TPR implies that the Court focuses on the quality of the domestic

13 ECtHR, Judgment (GC), 1 July 2014, S.A.S. v France, Application No. 43835/11, para. 129.

14 "Affirming that the High Contracting Parties, in accordance with the principle of subsidiarity, have the primary responsibility to secure the rights and freedoms defined in this Convention and the Protocols thereto, and that in doing so they enjoy a margin of appreciation, subject to the supervisory jurisdiction of the European Court of Human Rights established by this Convention".

15 See in particular ECtHR, Judgment, 12 June 2012, Lindheim and Others $v$ Norway, Application Nos. 13221/08 and 2139/10. 
process (legislative, administrative and judicial) in enacting and applying a particular piece of legislation that may interfere with an ECHR right. Gerards speaks for instance of the 'quality of the process and deliberations underlying a certain piece of legislation. ${ }^{16}$ These conditions are broadly democracy- and rule of law-based and include participation, inclusiveness, pluralism, independence, transparency, and proportionality. ${ }^{17}$ In Animals Defender International $v$. UK, which concerned the general prohibition of political advertising in broadcasting, the Court for instance insisted on the quality of the procedure across both parliamentary and judicial channels:

The Court, for its part, attaches considerable weight to these exacting and pertinent reviews, by both parliamentary and judicial bodies, of the complex regulatory regime governing political broadcasting in the United Kingdom and to their view that the general measure was necessary to prevent the distortion of crucial public interest debates and, thereby, the undermining of the democratic process. ${ }^{18}$

Surely, some of these procedural requirements form part of the proportionality test itself - for example, when the Court assesses that the interfering norm was 'prescribed by law' ( $1^{\text {st }}$ prong of the test for Articles 8-11 of the Convention). The TPR can also consist of the evidence that the domestic authority has taken into account ECHR standards (irrespective of if and how the authority might ultimately balance conflicting rights and interests). This is salient for instance in Axel Springer v. Germany (No. 2) in which the Court held that 'where the balancing exercise between those two rights has been undertaken by the national authorities in conformity with the criteria laid down in the Court's case-law, the Court would require strong reasons to substitute its view for that of the domestic courts'. ${ }^{19}$

It appears that the TPR does not consist of inherently new normative standards - rather, it is indirectly referring to well-established duties that correlate with some of the most developed provisions of the Convention, which also blurs the distinction between the two types of TPR drawn at the start of the article. The requirement of pluralism and contribution to public debate, which were central to the Court's conclusion in Von Hanno-

16 Gerards, 'Procedural Review by the ECtHR: A Typology' in in Brems and Gerards (eds) Procedural Review in European Fundamental Rights Cases (2017), 127 (140).

17 Ibid.

18 ECtHR, Judgment (GC), 22 April 2013, Animals Defender International $v$ The United Kingdom, Application No. 48876/08, para. 116.

19 ECtHR, Judgment, 10 July 2014, Axel Springer AG v Germany (No. 2), Application No. $48311 / 10$, para. 88 . 
ver v. Germany (No. 2) is part of the core content and scope of the right to freedom of expression and the right to assembly and association (Articles 10 and 11). ${ }^{20}$ In other words, while the literature dissociates the two kinds of review (procedural and substantive), in fact the TPR (understood as set of normative standards) is not foreign to the substantive case law of the Court, even if these standards are not presented as such in the text of the judgments and are often reviewed independently from the substantive merits.

What makes the TPR distinctive then? As I shall further explain in the next section, the TPR implies marginalising the balancing phase of the proportionality test that the Court routinely and independently operates. This marks the distinctive feature of the TPR, as opposed to any necessary link to the margin of appreciation or to any other interpretive tool or doctrine of the Court. This point is noted in the literature:

the focus is not on if and how procedural elements are made explicit as part of the protective scope of Convention rights, but on their significance among the balance of reasons when the Court pronounces on the substantive merits and assesses the proportionality or reasonableness of a measure. ${ }^{21}$

Commentators have pointed out the potential significance of this self-limitation vis-à-vis the very idea of human rights review. Kleinlein for instance explains that 'the quality of domestic law-making procedures is a factor that determines the authority of international human rights over domestic law. ${ }^{22}$ Nussberger writes that 'the very function of human rights review is to counter-balance majority decisions: $[t]$ his cannot be done be reviewing the procedure only. ${ }^{23}$ Descriptively, this seems accurate. Yet, when it comes to the properly normative significance of the TPR, the literature remains relatively scarce. One may ask: what is the importance of human

20 I developed this idea further in Zysset, 'Freedom of expression, the right to vote, and proportionality at the European Court of Human Rights: an internal critique' (2019) 17:1 Int. J. Const. Law, 230.

21 Arnardóttir, 'The "Procedural Turn" under the European Convention on Human Rights and Presumptions of Convention Compliance' (2017) 15:1 Int. J. Const. Law, 9 (14).

22 Kleinlein, 'The Procedural Approach of the European Court of Human Rights: Between Subsidiarity and Dynamic Evolution' (2019), 68:1 ICLQ, 91 (96).

23 Nussberger, 'Procedural Review by the ECHR: View from the Court' in Brems and Gerards (eds) Procedural Review in European Fundamental Rights Cases (2017), 161 (167). 
rights review in the first place, and how can one appropriately evaluate the TPR in light of that importance?

Since we saw above that one distinctive implication of the TPR is its impact on proportionality and balancing, the task of evaluating the TPR requires having a normative account of the proportionality in the first place. That is the methodological step that seems required before proceeding any further. The only properly normative accounts of the TPR emphasise democratic legitimacy and subsidiarity. Judge Robert Spano for instance has referred to the TPR as a 'qualitative, democracy enhancing approach' that essentially reformulates the principle of subsidiarity. ${ }^{24}$ Kleinlein writes that 'the current reformulation or refinement of the principle of subsidiarity has the potential both to enhance the democratic legitimacy of the Court's rulings and to stimulate domestic democracy. ${ }^{25}$ In that sense, the TPR does not amount to 'a retreat or deterioration of international human rights as fundamental values or a decline of the rule of law. ${ }^{26}$ What characterises these accounts is their empirical character - namely, that the TPR could (or could not) generate more democratic outcomes domestically. In my view, this further indicates the gap in the analysis, namely that it begs the question whether proportionality (or the absence thereof) makes any difference to our evaluation of the TPR.

In what follows, I argue that the TPR amounts to a deterioration of the right to justification, which I take to be foundational to the very idea of human rights and that operates in the proportionality test specifically. This argument is based on two premises also developed in the next section. First, that proportionality (and balancing in particular) crystallises a paradigmatic shift in constitutional and human rights law, namely the shift from authority to justification. Second, that the right to justification constitutes an essential normative foundation of human rights. These two premises lead to the conclusion that marginalising balancing and proportionality through TPR amounts to eroding the normative core of human rights and entrenches a culture of presumption. It could be that the TPR may enhance justification domestically but that remains an empirical question, not a conceptual one.

24 Spano, 'Universality or Diversity of Human Rights? Strasbourg in the Age of Subsidiarity' (2014) 14:3 Hum. Rights Law Rev., 487 (499).

25 Kleinlein, 'The Procedural Approach of the European Court of Human Rights: Between Subsidiarity and Dynamic Evolution' (2019), 68:1 ICLQ, 91 (110).

26 Kleinlein, 'The Procedural Approach of the European Court of Human Rights: Between Subsidiarity and Dynamic Evolution' (2019), 68:1 ICLQ, 91 (110). 


\section{The TPR, Proportionality and Justification}

\section{Authority and Justification}

The first premise to my argument delves into historical and conceptual developments as to the proper role of constitutional and human rights review. In their book Proportionality and Constitutional Culture, Cohen-Elyia and Porat conceptualise the prominent rise of proportionality as indicating a turn from a 'culture of authority' to a 'culture of justification.' While the authors do mention the ECHR and the margin of appreciation several times (in particular, in reference to the margin of appreciation as reflecting the 'inherent flexibility' of proportionality), ${ }^{27}$ they do not address the Court's concept of proportionality, its established practice or the recently developed TPR. Yet, I believe that their conceptual apparatus, and specifically the turn from authority to justification can help us assess the normative significance of the TPR, provided that we re-adjust the variables of the equation.

In a nutshell, authority and justification are two competing accounts of what confers legal decisions legitimacy. Both authority and justification have similar evaluative functions although their evaluative basis is distinct. On the one hand, a culture of authority 'is based on the government's authority to exercise powers. ${ }^{28}$ This already indicates that a culture of authority is concerned with whether the authority taking the decision is the appropriate one and less with the substantive merits. In analysing the culture of authority in the US context, Cohen-Elyia and Porat further explain that, assuming no violation of constitutional rights, 'a court will respect the autonomy of the authorised institution and bow to its special expertise when it identifies areas that are within the scope of the institution's exclusive authority. ${ }^{29}$ This goes to the core of the authors' account of legitimacy: 'the legitimacy and legality of a given action is derived from the fact that the actor is authorised to act.' ${ }^{\text {'30 }}$

27 Cohen-Eliya and Porat, Proportionality and Constitutional Culture (2013), 104. See also Möller, 'Justifying the Culture of Justification' (2019) 17:4 Int. J. Const. Law, 1078, and Kumm, 'The Idea of Socratic Contestation and the Right to Justification: The Point of Rights-Based Proportionality Review' (2010), 4:2 Law \& Ethics of Human Rights, 142.

28 Cohen-Eliya and Porat, Proportionality and Constitutional Culture (2013), 110.

29 Id., 114.

30 Id., 110. 
This seems to echo the jurisdictional considerations addressed earlier quite well - in particular, the organising notion of subsidiarity: when the Court asserts that domestic authorities are 'better placed' qua democratic entities to address the key phase of the proportionality test, namely balancing, it is expressing the view that only the domestic authority is appropriately place (normatively speaking). Indeed, it is well established that the balancing cannot be confined to a factual examination. Judges 'measure not only the extent of harm to each value but also make (at least implicitly) judgments regarding the relative importance of each to the conflicting values. ${ }^{31}$ Hence, the TPR, like the application of the margin of appreciation, cannot be grounded solely in epistemic reasons. The Court itself has admitted that democratic legitimacy has normative and decisive value when it comes to balancing. As we have seen, the Court held in S.A.S. $v$. France that national authorities benefit from 'direct democratic legitimation' in adjudicating contentious ethical questions.

Therefore, if one applies the notion of the culture of authority to the TPR, the argument would be that domestic authorities are the only authorised to make the decision - and to balance competing values and interests - because these decisions benefit from the verdict of democratic procedures. In other words, the TPR reflects an account of democratic legitimacy that is exclusively domestic and procedural. The implication of that account is the marginalisation - if not the complete exclusion - of proportionality qua balancing. Surely, it could be that the TPR reinforces the likelihood that the ultimate decision will be optimally democratic. But that is, again, a presumption. And we should recall that the TPR, as I understand it, is only one form of authority - another being the authority of the legal text or the authority of the methods of interpreting the text. In both cases, however, Cohen-Elyia and Porat conclude that 'balancing remains antithetical and, accordingly, marginalised in the culture of authority.' ${ }^{32}$

At this point it is worth zooming in further and examining which concept of democracy is underlying the Court's approach when it operates the TPR. In particular, it is worth asking why the exclusion of balancing is implicitly taken as potentially interfering with democracy. Surely, only a strongly procedural and majoritarian notion of democracy can explain why the Court reviewing domestic processes is defined as an interference: the outcome of the process is taken as a verdict of legitimate authority.

31 Id., 109.

32 Id., 119. 
This is precisely where the boundary between authority and justification lies: authority is insensitive to the substantive reasons that ultimately justifies a domestic balancing conflicting rights and interests. It is presumed that the task of justification is and ought to be reserved to the domestic process, and the TPR will only require that the Court reviews domestic processes leading to the decision but not the decisive reasons that struck the balance. Justification, we shall see next, rather suggests that authority alone is never enough for normative legitimacy. The fact that only a domestic authority is endowed with procedural(-democratic) credentials is not enough for its verdict to be automatically legitimate to its subjects whether that applies to the applicant to a particular case or, in fact, to every individual constructed as free and equal.

\section{From proportionality to justification...}

The upshot so far is that a culture of justification aims to confer normative legitimacy to norms and decisions. A culture of justification 'derives from the court's role and from the idea that government action is not legitimate when it is not justified. ${ }^{33}$ Yet, while correctly highlighting the paradigmatic shift from authority to justification that proportionality signals, CohenElyia and Porat do not define the normative criteria of justification in great length and how exactly justification operates in the balancing phase of proportionality. This is where I suggest operating a disciplinary turn and delve into the independent and properly moral notion of (the right to) justification as it has been developed in human rights theory in recent years. I believe that this excursus can help measure the deficit that the TPR implies: the right to justification remedies the deficit of an independent variable for evaluating the loss.

Before doing that, it is important to explain in what sense could the Court's practice of the proportionality test be understood as an exercise of justification at all. If one looks at the structure and wording of the Court's test, one may depict it as an exercise of ad hoc assessment of the reasons for interfering with one or several rights of the Convention. For example, one may find an instance of justification when the Court assesses the 'legitimate aim' of the interference (after having established its legality through the 'prescribed by law' step). Yet, as the literature has shown, the Court treats this second step as an exercise of classification rather than justifica- 
tion - and, as a result, only rarely finds an interference at this particular stage. ${ }^{34}$ One may therefore expect that the last step of the test, the one of balancing, implies some justificatory reasoning properly speaking. This is where the Court enjoys a wider discretion for scrutinising the reasons that the respondent state had for interfering with one or several rights of the Convention - after having found a prima facie violation through its established interpretive principles with respect to a particular to article of the Convention.

Yet, if turning to the reasons for states to interfere with rights might seem facially justified, one may still wonder if the Court necessarily engages in justificatory reasoning when it conducts proportionality analysis and balancing. Indeed, this would require the Court to have an independent definition for determining when an interference is 'excessively burdensome,' as the Court puts it, or that 'it responded to a pressing social need' and was 'necessary in a democratic society.' This particular wording of the balancing phase of the test (found in the text of the Convention under Articles 8-11) suggests that there is indeed a tipping point beyond which an interference is not justifiable and, correlatively, that the Court has a metric for identifying this point. The same applies when the Court grants a margin of appreciation - it often says that the state 'did not exceed its margin of appreciation' without necessarily explaining where the tipping point is exactly located. Yet, nothing in this approach is necessarily based on a culture of justification - rather, it amounts to reintroducing authority by presuming that such an independent basis is or could be derived from the text of the Convention or ultimately from a method of adjudication (e.g. 'evolutive and dynamic', 'autonomous concepts,', 'practical and effective'). Relying on a (self-created) method of interpretation only seems to add to the justificatory burden of what, ultimately, makes this or that method justifiable and applicable in a particular case. One method that receives far less emphasis, as commented by Möller, is interpretation: 'rather than applying a conventional set of interpretative methods to the constitutional text, courts tend to read constitutions in a way that requires or allows them to focus on the substantive justifiability of the act in question. ${ }^{35}$

34 Gerards and Senden, 'The Structure of Fundamental Rights and the European Court of Human Rights' (2009) 7:4 Int. J. Const. Law, 619.

35 Möller, 'Justifying the Culture of Justification' (2019) 17:4 Int. J. Const. Law, 1078 (1084). 
What this makes clear is that one cannot define the Court's proportionality test as justificatory without an independent notion of justification. The very idea of justification inheres in our status of human beings as having the distinctive capacity to form, to reflect upon, to assess, to respond to and to act upon reasons. I shall build upon this properly philosophical and ontological account to explain how it can justify and structure the proportionality test and balancing. Most famously, Forst has advanced the notion regarding our status as agents of justification as 'a basic concept of practical reason and as a practice of moral and political autonomy - as a practice that implies the moral right to justification and that grounds human rights on that basis. ${ }^{36}$ As such, respecting the right to justification of an individual requires that she is not subjected to norms, practices and institutions that cannot be justified to her. This deontological account has an important generality and reciprocity dimension in that the justification must be mutual - 'no one may make a normative claim (such as a rights claim) he or she denies to others [...].'37 Forst further explains that human rights law plays a crucial role in making this overarching moral right effective: 'the legal and political function of human rights is to make this right effective, both substantively and procedurally. ${ }^{38}$,

How could one observe the right to justification operating in the review structure of the Court? This is where the TPR and proportionality qua procedures become highly relevant as they generally are portrayed as performing justificatory functions in the Court's decisions, as we have seen above. As we have also seen, however, the TPR places the justificatory burden upon the democratic process of state parties but without evaluating the ultimate reasons offered by the domestic authorities, hence a deficit of justification. Further, a majoritarian approach to the democratic process cannot simply be presumed to have respected the right to justification of its subjects. Proportionality constitutes the guarantee that the right is respected at the procedural level: courts will filter the reasons that may indeed justify interfering with rights even if the interfering norm benefits from democratic legitimacy. In other words, the independent notion of justification put forward here is grounded in an ontological account of human beings andits normative implications reach both the substantive and procedural dimensions of human rights law.

36 Forst, 'The Justification of Human Rights and the Basic Right to Justification: A Reflexive Approach' (2010) 120:4 Ethics, 711 (712).

37 Id., 711 (719).

38 Ibid. 


\section{And back...}

How could proportionality more precisely operate a justificatory function in the sense presented above? Proportionality embodies the procedural dimension of the right to justification. Beyond the substantive list of rights that cannot be justifiably denied to free and equal individuals, the proportionality test further aims to offer individuals justifiable reasons for the norms and decisions to which they are subjected. This step is crucial to the claim that the TPR, by marginalising proportionality and balancing, amounts to a deterioration of the right to justification. Kumm suggests that proportionality should be viewed as part of the very normative point of human rights, which is defined around a liberal account of freedom and equality: 'a conception of law and politics as justice-seeking among free and equals. ${ }^{39}$ Unlike conceptions of human rights that define these rights as a distinctive subset of moral rights ${ }^{40}$, here, the normative basis of human rights is confined to an ethically thin notion of freedom and equality of moral status. This status is not only expressed in the substantive list of rights that one commonly finds in conventions, treaties, bills and constitutions. It is also expressed in the procedural practices of adjudicating these rights.

On the one hand, the right to justification is expressed in the individual being conferred the right to challenge norms and decisions in court through judicial review. As stated by Kumm, 'human rights norms empower rights-holders to challenge existing power relationships by insisting that those relationships be susceptible to justification in terms of public reason' (emphasis added). ${ }^{41} \mathrm{Kumm}$ goes further to say that, 'the structure of human rights adjudication is geared towards establishing whether or not a particular legal norm burdening an individual can be demonstrably justified to that individual under this standard. ${ }^{42}$ This account builds upon some characteristic features of human rights lists around the world, such that the scope of legally enshrined rights not being limited to a particularly basic domain, or such that rights may be limited by restriction clauses (e.g. national security, public health, the impartiality of the judiciary, etc.)

39 Kumm, 'The Turn to Justification: On the Structure and Domain of Human Rights Practice' in Etinson (ed), Human Rights: Moral or Political? (2018), 57.

40 See for instance Griffin, On Human Rights (2008), chapter 1.

41 Kumm, 'Is the Structure of Human Rights Practice Defensible? Three Puzzles and Their Resolution' in Tushnet and Jackson (eds), Proportionality: New Frontiers, New Challenges (2017), 30 (65). 
The restriction clauses (e.g., in Articles 8-11 ECHR) come to the fore precisely in the proportionality test where the Court turns to the arguments given by the respondent state, which regularly claim the interference with of a right remained within the broad parameter of the clause. Those restriction clauses are in principle problematic as they have an open-ended character - and that is where the Court needs to deploy a higher degree of justificatory reasoning in balancing competing rights and interests. In the Court's case law, this higher degree is seen in the quite lengthy paragraphs, usually located towards the end of a judgment, where the Court examines whether the interference was 'necessary in a democratic society' and responded to 'a pressing social need'. As we have seen, however, the Court often falls back onto one variant of authority typically, through the margin of appreciation or by simply relying on the TPR to reach a conclusive decision. Yet, the more it relies on authority at this particular stage, the less it engages with the right to justification of individuals.

At this crucial stage, Kumm believes that the right to justification explains the crucial role of the proportionality test in ruling out reasons that cannot be justified to free and equal individuals. Kumm targets what he calls 'political pathologies' - for instance, when religious justifications are used for treating homosexuality as a sin. The reason offered cannot pass the following test: 'this type of reason, a reason relating to what it means to live a good, authentic life, might not generally count as legitimate reasons to restrict someone's right. ${ }^{43}$ Rather, it constitutes a comprehensive moral view that amounts to exercising arbitrary power over individuals, and as such is not legitimate. The deontological basis of the right to justification is therefore at odds with any ethically comprehensive, perfectionist, or consequentialist account of the good. For example, when the Court in S.A.S. $v$. France asserted that in matters of general policy, on which opinions within a democratic society may reasonably differ widely, the role of the domestic policy-maker should be given special weight' ${ }^{\prime 4}$ and subsequently granted the respondent state a margin of appreciation, the Court did not assess whether the ban on the veil amounted to a particular comprehensive

43 Kumm, 'The Idea of Socratic Contestation and the Right to Justification: The Point of Rights-Based Proportionality Review' (2010), 4:2 Law \& Ethics of Human Rights, 142 (159).

44 ECtHR, Judgment (GC), 1 July 2014, S.A.S. v France, Application No. 43835/11, para. 154. 
idea of 'living together' ${ }^{4}$. In that sense, the TPR runs the risk of lowering the bar of justification.

\section{Conclusion}

This article was a first step in the project of offering a normative analysis of the TPR. The premise to this project was that the recent contributions to this topic very helpfully illustrate, categorise and analyse the TPR in the Court's case law but fall short of evaluating this judicial evolution in normative terms. How should one place this evolution in a broader understanding of the purpose of human rights review, on the subsidiary role of the Court and ultimately on the very idea of human rights? I have argued that the TPR points to worrying implications in terms of the justificatory function that human rights review in general and proportionality analysis play. The intermediate step here has been to explain how proportionality operates a justificatory function - a point that the literature in constitutional and human rights theory has recently developed, but which so far has not been utilized in the context of the TPR. I have connected these two strands of the literature through one distinctive implication of the TPR, which is the retreat from the balancing phase of proportionality and the increased weight put on the domestic procedure in informing the merits of a case. One may claim that the emphasis put on the domestic procedure in fact strengthens the right to justification domestically, but when this emphasis amounts to marginalising the Court's own review of proportionality, the TPR implies a presumption rather than a justification.

\section{Bibliography}

Arnardóttir, Oddný Mjöll: The 'Procedural Turn' under the European Convention on Human Rights and Presumptions of Convention Compliance, Int. J. Const. Law 2017, 9 fff.

Brems, Eva: Procedural Protection: An Examination of Procedural Safeguards Read into Substantive Convention Rights, in: Brems, Eva/Gerards, Janneke (eds), Shaping Rights in the ECHR: The Role of the European Court of Human Rights in Determining the Scope of Human Rights (2014), $137 \mathrm{ff}$.

Cohen-Eliya, Moshe/Porat, Iddo: Proportionality and Constitutional Culture (2013).

45 Id., para. 82. 
Forst, Rainer: The Justification of Human Rights and the Basic Right to Justification: A Reflexive Approach, Ethics 2010, 711ff.

Gerards, Janneke: Procedural Review by the ECtHR: A Typology, in: Brems, Eva/ Gerards, Janneke (eds), Procedural Review in European Fundamental Rights Cases (2017), 127ff.

Gerads, Janneke: The Prism of Fundamental Rights, Eur. Const. Law Rev. 2012, $173 \mathrm{ff}$.

Gerards, Janneke/Senden, Hanneke: The Structure of Fundamental Rights and the European Court of Human Rights, Int. J. Const. Law 2009, 619ff.

Griffin, James: On Human Rights (2008).

Kleinlein, Thomas: The Procedural Approach of the European Court of Human Rights: Between Subsidiarity and Dynamic Evolution, ICLQ 2019, $91 \mathrm{ff}$.

Kumm, Mattias: Is the Structure of Human Rights Practice Defensible? Three Puzzles and Their Resolution, in: Jackson, Vicki C./Tushnet Mark (eds), Proportionality: New Frontiers, New Challenges (2017), 30ff.

Kumm, Mattias: The Idea of Socratic Contestation and the Right to Justification: The Point of Rights-Based Proportionality Review, Law \& Ethics of Human Rights 2010, 142ff.

Kumm, Mattias: The Turn to Justification: On the Structure and Domain of Human Rights Practice, in: Etinson, Adam (ed), Human Rights: Moral or Political? (2018), 57ff.

Kumm, Mattias: Letsas, George: Two Concepts of the Margin of Appreciation, Oxf. J Leg. Stud. 2006, $705 \mathrm{ff}$.

Möller, Kai: Justifying the Culture of Justification, Int. J. Const. Law 2019, $1078 \mathrm{ff}$.

Nussberger, Angelika: Procedural Review by the ECHR: View from the Court, in: Brems, Eva/Gerards, Janneke (eds), Procedural Review in European Fundamental Rights Cases (2017), 161ff.

Spano, Robert: Universality or Diversity of Human Rights? Strasbourg in the Age of Subsidiarity, Hum. Rights Law Rev. 2014, 487ff.

Zysset, Alain: Freedom of expression, the right to vote, and proportionality at the European Court of Human Rights: an internal critique, Int. J. Const. Law 2019, $230 f f$. 